\title{
Cervical Cancer cT1b TNM Finding v7
}

National Cancer Institute

\section{Source}

National Cancer Institute. Cervical Cancer CT 1b TNM Finding v7. NCI Thesaurus. Code C89484.

Cervical cancer with clinically visible lesion confined to the cervix. (from AJCC 7th Ed.) 